\title{
State-Society Relations: NGOs in Kazakhstan
}

\author{
Colin Knox and Sholpan Yessimova \\ Journal of Civil Society, 2015 Vol 11 (3): 300-316
}

\begin{abstract}
Kazakhstan has provided the economic exemplar for other Commonwealth of Independent State (CIS) countries since its independence in 1991 following the collapse of the Soviet Union. It has been classified by the World Bank as an 'upper middle income' country and witnessed sustained growth in spite of the global recession. Political reforms however have been slower to realise and the Presidential Republic still remains a highly centralised and autocratic regime. Some 23 years beyond independence this paper assesses whether the role played by the NGO sector has changed and, as a consequence, the asymmetric statesociety fulcrum has shifted in favour of a stronger societal voice in Kazakhstan. It finds mixed evidence of partnership between NGOs and Government and ongoing problems in exercising public voice and moderating the power of the state.
\end{abstract}

\section{Introduction}

There are claims and counterclaims about how serious Kazakhstan, a former Soviet republic, is in its attempts to democratise. On the one hand, critics argue it is a repressive regime which stifles opposition, limits press freedom and suppresses the growth of civil society (Kelly, cited in Nichol, 2013; Amnesty International, 2013). The National Social Democratic Party Azat, for example, argued that Kazakhstan has 'an ugly political system which apart from trampling upon citizens' rights and freedoms creates a pseudo-democratic façade' (Kosanov, 2010: 2). On the other hand, supporters claim Kazakhstan is a young democracy, has made significant achievements when judged against the progress of other Central Asian countries, and is committed to political and civil society reforms at a pace consistent with its low starting point. As the Minister for Foreign Affairs put it: 'please don't expect Jefferson's democracy today, tomorrow, or even the day after.... it will come if evolution allows' (Idrissov, 2013:1). Critics cite a concentration of power in the executive branch of government (representing the state) under the tight control of the President which dominates both the legislative branch (parliament) and the judiciary. There is an inadequate system of checks and balances and hence the legislative and judicial powers provide a mechanism for the controlling executive power, also referred to as 'soft authoritarianism' (Schatz, 2009; Schatz and Maltseva 2012). Freedom of speech is guaranteed by the Constitution but effectively restricted by: constitutional provisions protecting 'honour and dignity'; the continued criminalisation of defamation and insult; and, the higher protection afforded to the President and public officials (insulting the President and senior officials is a criminal offence). The Civil Code does not provide for a limit to damages awarded for defamation and insult or for a limitation period. According to the Organisation of Security 
and Co-operation in Europe (OSCE) 'the fact that defamation and insults can still result in imprisonment, and an increasing number of lawsuits with exorbitant damages are awarded against journalists and media outlets, induce restraint and self-censorship'(OSCE, 2011: 12).

One example is the media coverage of a protest by oil workers in the Caspian port city of Zhanaozen (west Kazakhstan) in December 2011. This erupted into violence between police and protestors where, according to Opposition activists and human rights campaigners, over 70 people were killed and 400 injured when police opened fire (Moscow News, 2012). The government imposed a media crackdown and arrested Kazakh opposition protestors including the leader of the liberal Alga Party, Vladimir Kozlov, and editor-in-chief of the Vzglyad newspaper, Igor Vinyavsky in the wake of the protests. In January 2012, five senior security officers were charged with abuse of office in relation to the use of force in Zhanaozen and were sentenced to between five and seven years in prison.

Corke, in evidence to the US Commission on Security and Cooperation in Europe, has argued that Kazakhstan is 'heading down a path of increasing instability' (Corke, 2012: 2). She cites: the way in which the social unrest in Zhanaozen has been handled by the Kazakh authorities; unfair elections and significant restrictions on multi-party competition; tightening controls on religious freedoms and public expression; and, a clamp down on media outlets extended further to websites with 'destructive' content. Specifically referring to civil society, Corke argued:

Civil society in Kazakhstan had already operated under tightly controlled and repressive conditions, with government harassment, including police visits and surveillance of NGO offices and personnel. Real civil society efforts have been squeezed out by government NGOs which the government mobilised to create the impression of a thriving Kazakhstani civil society in the West (Corke, 2012: 7)

She recommended an increase in material support for civil society in Kazakhstan in cases of direct repression against NGOs and their activists.

The focus of this paper is to examine if civil society has, since the independence of Kazakhstan in 1991, played a role in the democratisation process. Despite evidence of growing political stability, albeit under a highly centralised Presidential Republic, the paper explores the role of civil society as a potential independent voice and a bulwark against a centripetal regime. Our starting point draws on the seminal study of Luong and Weinthal (1999) on environmental non-governmental groups working specifically in the energy sector in Kazakhstan. Their work, more generally, offered an early assessment of state-society relations in Kazakhstan. They argued that support for NGOs, from the perspective of Western liberal democracies, is perceived as 'initial building blocks of a civil society'. Their study highlighted the adverse impact of the political climate on the development of an active NGO sector and concluded that: 'overall, NGOs face insurmountable difficulties in Kazakhstan owing to the limited degree of democratisation that has taken place in the 
system as a whole since independence...NGOs' goals and strategies are constrained by the very government they are trying to influence' (Luong and Weinthal, 1999:1276). Some 15 years on from their original study we assess whether the role played by the NGO sector has changed and, as a consequence, the asymmetric state-society fulcrum has shifted in favour of a stronger societal voice in Kazakhstan. Given the importance of context, we begin by examining the political milieu in which civil society is located.

\section{Background and political context}

Kazakhstan is a central Asian state which is bordered by Russia, China, Kyrgyzstan, Uzbekistan, Turkmenistan and the Caspian Sea. It is a vast country of steppes, mountainous areas and desert with a population of some $16.9 \mathrm{~m}$ people of which around $60 \%$ are Kazakhs, 25\% Russians, and the remainder a huge mix of ethnically diverse groups (more than 130 ethnic groups and 40 religious denominations) (Kazakhstan Agency of Statistics, 2014). Historically, Kazakhstan was recognised in 1936 as a full union republic of the USSR. With the collapse of the Soviet Union in December 1991, Kazakhstan declared independence and joined the Commonwealth of Independent States (CIS) under President Nursultan Nazarbayev (former head of the Kazakh Communist Party) who won uncontested elections with $91 \%$ of the vote (Cummings, 2001 and 2002).

In the first decade following independence there were three stages of reform: (a) dismantling the Soviet control system and Communist Party political monopoly; (b) change in the political structures consistent with the separation of powers (executive, judicial and legislative) adopted through the first Constitution in 1993; and (c) the election of a bicameral Parliament with a new Constitution in 1995 (Isaacs, 2010). Presidential elections took place in 1999, two years ahead of schedule while the economy was growing, and Nazarbayev was re-elected with $82 \%$ of the vote, although the OSCE expressed concerns about fairness and irregularities. Further Presidential elections were held in 2005 with Nazarbayev taking some $91 \%$ of the vote. Again the OSCE recorded a number of significant shortcomings in the election process. In 2010 the President's grip on power tightened further when legislation was introduced which designated him 'Leader of the Nation' and gave him and his immediate family life-long immunity from investigation and prosecution. The law gives Nazarbayev the power to veto legislation and address Parliament at will, even when he is no longer President. This followed a popular uprising in neighbouring Kyrgyzstan which ousted President Kurmanbek Bakiyev and caused concerns amongst other Central Asian leaders about their own positions (Cummings, 2012).

In December 2010 a public campaign was launched in support of a national referendum to extend the President's term of office until 2020 without elections. This was declared unconstitutional and the President went to the polls in April 2011 where he was re-elected for a third term with $95.5 \%$ of the vote in a poll boycotted by opposition parties. In 2012 , 
parliamentary elections (Mazhilis) were held in which the President's Party (Nur Otan) won 83 of the 98 seats available. OSCE observers noted that the elections 'did not meet fundamental principles of democratic elections' and that the authorities 'did not provide the necessary conditions for the conduct of genuinely pluralistic elections. Several political parties were blocked from standing and a number of candidates were de-registered without due process' (OSCE, 2012: 3).

President Nazarbayev challenges critics of his regime pointing to significant achievements in a relatively young independent nation, given its origins and the need for strong leadership from the outset (Kubicek, 1998). The Presidential Republic of Kazakhstan got off to a difficult economic start as the country experienced industrial recession, hyperinflation and a significant decline in living standards, despite its rich mineral resources. In part, these problems emerged because of Kazakhstan's entry into a market-based economy where it lacked knowledge and experience. The President responded with a series of tough economic reforms and, in so doing, extended his power base over Parliament which wavered in its resolve to tackle deepening problems facing the country. Since 1999, strong oil prices and a good macro economic performance resulted in a sustained period of economic growth. Health spending increased 10 times in the last decade, higher pensions and more jobs have reduced the number of people living in poverty, literacy rates are almost $100 \%$, and there are generous scholarships for young people to study abroad (World Bank, 2013).

Kazakhstan has also witnessed a picture of healthy economic performance in the midst of a global economic downturn. The World Bank classifies Kazakhstan as an 'upper middle income' country with an annual percentage GDP growth rate of $5 \%$ in 2012, and an unemployment level of 5.3\% (World Bank 2014). This oil-producing country ranks in the top 10 fastest growing countries, according to the International Monetary Fund (IMF, 2014). By 2016, GDP per capita in Kazakhstan is expected to reach 15,000 US\$ (from its current 12,000 US\$) at which point it will be classified by the World Bank as a 'high income economy' according to the former Deputy Prime Minister Kairat Kelimbetov (Ernst and Young, 2013).

Kazakhstan sees itself as an important bridge connecting East and West through promoting good relations between Russian, the United States, Europe, China and beyond. It has been described as the 'New Silk Road' that connects the East with Europe, Turkey and the Middle East. Dismantling the nuclear arsenal which Kazakhstan inherited after the collapse of the Soviet Union and signing the Nuclear Non-Proliferation Treaty testifies, it claims, to a voice for moderation and peace. This reflects a tolerant society within its own borders where people of all backgrounds and religions have co-existed without violence or splits along ethnic or religious lines (Matakbaeva, 2013). The fact that Kazakhstan became the first former Soviet state to chair the OSCE, despite its democratic credentials, is evidence of growing international recognition and the country's attempts to implement political reforms characterised in its motto of the four Ts - trust, tradition, transparency and tolerance 
(Bhuiyan, 2012). The President argued: 'it took the great democracies of the world centuries to develop. We are not going to become a fully developed democracy overnight. But we have proved that we can deliver on our big ambitions. Our road to democracy is irreversible, and we intend to provide economic and political opportunities for our citizens' (Nazarbayev, 2011: A17). None of Kazakhstan's neighbours have adopted such democratic reforms and the country is coming under greater threat from terrorism, illegal immigration, drug and people trafficking and religious extremism, as it opens up and liberalises (Schmidt, 2013). Such liberalisation includes a growth in civil society.

External factors have played an important role in the development of civil society in Kazakhstan. Silitski (2010), for example, examined the internal and external reactions by post-Soviet countries to the 'coloured revolutions' in Georgia, Ukraine and Kyrgyzstan (see also Cummings and Ryabkov, 2008). He described an authoritarian backlash aimed at buttressing surviving autocracies, citing Kazakhstan as an example of a country which feared revolutionary contagion. He noted the refusal to publish independent newspapers on the eve of the presidential elections in December 2005 and 'even tighter restrictions on NGO activities in Kazakhstan under the semblance of anti-terrorist laws' (Silitski, 2010: 342). Silitski concluded that the autocratic reaction in Kazakhstan to the coloured revolutions undermined any efforts to develop a strong and organised opposition and civil society and stymied attempts to generate a democratic and pluralist society.

\section{Definition and scope}

The starting point in examining state-society relations is to offer a working definition of civil society of which there are many (Foley and Edwards, 1996; Candland, 2001; Deakin, 2001; Jenson, 2006; Keane, 2009; Lewis 2009; Buxton, 2011). Keane (2009: 461), for example, refers to civil society as 'a dynamic ensemble of legally protected non-governmental organisations that tend to be non-violent, self organising, self-reflexive, and permanently in tension, both with each other and with governmental institutions that 'frame' constrict and enable their activities'. However, given the origins of civil society in Kazakhstan we draw on Crotty's research (2009) which examined NGOs and civil society in Russia. She offers a more context-relevant definition, derived from Kuchukeeva and O'Loughlin's work in Kyrgyzstan, in which civil society is defined as 'the sphere ... situated between the state and the market which can serve as a promoter of democratic values, provide models of active citizenship, and temper the power of the state' (Kuchukeeva \& O'Loughlin, 2003, 557-58).

In addition to adopting a working definition there is a need to enumerate the size and composition of civil society in Kazakhstan which is also challenging. The non-profit sector is regulated through two pieces of legislation: On Public Associations (1996) and On NonCommercial Organisations (2001). However, these laws include a variety of organisations such as joint stock companies, consumer co-operatives, religious associations, foundation unions and associations, making it difficult to differentiate the traditional boundaries of civil 
society. Following independence in 1991, there was a flurry of activity and more than 400 non-governmental organisations were established mainly in the areas of human rights and democratisation, consistent with the reforms agenda in Kazakhstan (Huseyin, 2003). This growth was accelerated through assistance from international donors in the United States and Europe during the late 1990s. Currently the Department of Social and Political Work, in the Ministry of Culture and Information, lists more than 35,000 non-profit organisations, including 18,000 NGOs. There is however uncertainty about the numbers involved. Nezhina and Ibrayeva (2013), for example, claim that many of the registered NGOs are dormant or non-functioning and estimate that the number of active NGOs in the whole country amounts to little more than 800 . These numbers are at odds with research by Makhmutova and Akhmetova (2011) who claim there are currently 8,000 NGOs in Kazakhstan of which 2,000 are active. Kazakh legislation allows for NGOs which are created specifically to implement state social contracts and non-commercial organisations which include nonprofits such as religious groups and labour unions - government officials use these terms interchangeably and hence create difficulties in researching the NGO sector (Asanova and Sedova, 2013)

The functional activities undertaken by NGOs include: environment (15\%); children and young people (14\%); women (13\%); medical (13\%); culture, arts, science and education (12\%); human rights (8\%); social welfare (7\%); community initiatives (7\%); disability and rehabilitation of children (7\%); and miscellaneous (4\%) (Ministry of Culture and Information, Kazakhstan 2013). Although civil society encompasses a much wider role than the work of NGOs, given problems in identifying the scope of civil society in Kazakhstan, the focus of this research is on NGOs which represent 'building blocks of a civil society', to adopt Luong and Weinthal's (1999: 1267) frame of reference.

\section{Literature review}

What does the extant literature and scholarship tell us about civil society in Kazakhstan? The limited scholarship on civil society in Kazakhstan can be summarised as ranging from a sector which works in partnership with government through public services provision and is meeting social development challenges, to one which is almost entirely controlled and regulated by the state, offering a fig leaf for claims of greater democratisation and the strengthening of voice and accountability. According to Makhmutova and Akhmetova (2011: 3), knowledge about the state of civil society in Kazakhstan is limited and two contrary views are held: that civil society is a strong and influential actor; and, that civil society is embryonic. The evolution of civil society in Kazakhstan is rooted in the Soviet system where non-governmental activities were confined to youth, sports, cultural and scientific organisations. By the 1960s however social movements began to emerge which confronted the dominant party and state structures, demanding new economic and political ideas and approaches as the Soviet Union weakened (Jas Tulpar, for example, united many Kazakh 
students studying in Moscow against repression and raised the question of national identity). The period of perestroika associated with Mikhail Gorbachev in the 1980s created the conditions for greater openness, pluralism and independent civil initiatives in Kazakhstan. This period witnessed the growth of political groups such as Adilet and Azat which were actively critical of the totalitarian system of government and promoted the democratisation of society, and environmental groups, an example of which is Nevada Semipalatinsk that successfully campaigned for the closure of a nuclear testing site.

Kazakhstan's political antecedents therefore make literature on civil society in post-Soviet Russia relevant to our examination of Kazakhstan. Noteworthy is the work of Crotty (2009) and, more recently, Ljubownikow, Crotty and Rodgers (2013). The former examined the environmental movement in Russia and its impact on the development of civil society and concluded that 'despite 'kernels' of civic activism that were present at the time of the collapse of the Soviet Union, Russian civil society remains weak and ineffective in the face of an ever strengthening state' (Crotty, 2009:87). In their most recent work they report that the state now plays 'a dominant, directing and all-encompassing role with regard to civil society formation and development' (Ljubownikow et al, 2013, 155). A significant lesson from this scholarship is the call to understand civil society in Russia (which they describe as civil society po-russki) as 'a sphere shaped by its context, rather than constituting a driving force for democratization within that context' (Ljubownikow et al, 2013, 163). In short, the Western perception of the roles played by civil society in strengthening democracy and challenging the state simply do not transfer to post-Soviet countries. The wider relationship between civil society and strengthening democracy has been discussed by Evers (2010: 116) who argued that not only does it take 'social capital to make democracy work' (Putnam, 1993:185) but the opposite applies - 'it takes democracy to make social capital work'.

An interesting literature has also developed on civil societies in authoritarian regimes which offers a theoretical framework to help understand Kazakhstan (Cavatorta and Durac, 2011; Rivetti and Cavatorta, 2013; and Cavatorta and Durac, 2014). Scholars in this area challenge the assumption found in democratization studies which suggests that a strong civil society is a sine qua non for transition from authoritarian regimes. Rather, they argue, there is authoritarian resilience to civil society groups in which, through a process of state domination and co-optation, their voice is muted and to all intents and purposes there is no obvious dissent - a superficial stability exists. In short, the liner path between a strong civil society and democracy (as suggested in table 1 below) does not exist. The key assumptions of transitology no longer seem able to explain how democracy and authoritarianism can coexist in countries which have been described as 'liberalized autocracies'(Brumberg cited by Aarts and Cavatorta, 2013), a term which seems apposite for Kazakhstan. Hence, Aarts and Cavatorta, in their work on civil society in Syria and Iran, argue that instead of civil society activism being linked directly with democratization, 'a more neutral definition, stripped of its liberal normative content, can be a more useful tool to analyse what the reality of 
activism is on the ground in authoritarian systems rather than what liberal democrats would like it to be' Aarts and Cavatorta, 2013: 6).

In a fascinating series of case studies which explore civil society in China, Cuba and Russia, Froissart (2014b), Geoffray (2014) and Daucé (2014) respectively, explain how 'organised contention can co-exist with authoritarian rule and even consolidate it' (Froissart, 2014a: 222) - see also the work of Lideaur (2012) on Myanmar; Strecansky (2012) on Slovakia and Shin (2012) on South Korea. . Geoffray's study of Cuban provides evidence of 'channelling' citizens' claims towards specific social and cultural issues and, in so doing, has prevented political dissent. This has the effect of isolating or marginalising political dissidents from other dissenters. In Cuba, she argues 'the government has managed to combine political opening, selective repression and channelling tactics in order to avoid the emergence of a unified contentious movement' (Geoffray, 2014: 234). Daucé, using a case study of the Moscow Helsinki human rights group, finds evidence of 'hybridity' by the Russian authorities - repression of activists sitting alongside institutionalises co-operation with NGOs through grants. She argues that this hybrid policy has led to a decline in violence against activists and 'the civility of oppression exerted by the government over NGOs' (Daucé, 2014: 239). Froissart, using case studies of the rights of migrant workers in China, shows how some legal activists have used the law (public interest litigation and administrative law) to empower civil society. She concludes that these new forms of political participation 'take place within the authoritarian regime and should be understood as being an integral part of its mode of operation rather than a means to spread democracy and the rule of law' (Froissart, 2014b: 268). In short, these research contributions show that authoritarian regimes endure 'in part thanks to certain forms of discontent by showing that the way they are expressed is an integral part of authoritarian governance' (Froissart, 2014a: 219). The work rejects the idea of 'authoritarian resilience' through suppression of discontent but rather highlights mechanisms used by illiberal regimes to depoliticise organised contention so that authoritarianism and elements of democracy can subtly co-exist.

Turning specifically to existing research on Kazakhstan, Ziegler's work (2010) offers a comprehensive account of the sector. He describes the state's dominance of civil society as less thorough than in Uzbekistan, Turkmenistan or Belarus yet the sector is weaker than in the Baltic states or the Ukraine. Ziegler's research addresses how Kazakhstan has managed the tension between building a post-communist state and, at the same time, trying to accommodate an embryonic civil society. He argues that Kazakhstan has an 'in-between' form of civil society which does not fit the traditional roles of either 'fostering civil responsibility in a democratic polity or providing a protected sphere which resists the tyrannical (communist) state' (Ziegler, 2010: 799). Instead he suggests that the role of civil society is in flux because it sits between a centralised, absolutist state and an unrealised stable democracy. He concludes that the state has accommodated civil society 'by coopting, regulating and pressuring civil society organisations into a cooperative rather than a 
confrontational relationship with the state' and is therefore different from civil society in liberal democratic societies (Ziegler, 2010: 815). In summary, he suggests:

Kazakhstan's civil society is less willing to confront the state, more cooperative with the authoritarian system, and wary of the potential for civic activism to degenerate into instability. Few civic organizations have the resources to sustain their activities without state backing, so civil society has evolved into a mix of grass-roots organizations and groups sponsored and supported by the state...While contestative elements are not entirely absent in Kazakhstan's civil society, they have at least for now been implicitly subordinated (or sacrificed) in return for effective governance (Ziegler, 2010: 816).

Other researchers are however more supportive of, and positive about, the role played by civil society, a number of whom are Kazakh scholars. Bhuiyan and Amagoh (2011), for example, argue that NGOs perform an essential role in the delivery of public services and that the political context has been supportive of the growth and development of civil society in Kazakhstan. They suggest even greater potential for a vibrant civil society in the development and maintenance of democracy and good governance. Drawing on the work of Ovcharenko (2004) who examined obstacles to cooperation between the State and civil society, they conclude that the Government of Kazakhstan 'has endorsed the functions of civil society as essential tools for ensuring the quality delivery of public services' (Bhuiyan and Amagoh, 2011: 240). Specifically in the area of health care reform in Kazakhstan, Amagoh (2011) contends that there are now well developed partnership models where staff are shared between public sector agencies and NGOs who are also involved in health sector policy-making. Since 2005, he argued that the government started to allocate public funds to NGOs working on the prevention of 'socially significant' conditions and this has been significant in the delivery of health care: 'the flexibility, autonomy, and responsiveness of NGO structures have made a difference in the speed and effectiveness of primary health care services reform' (Amagoh, 2011: 575 citing Kulzhanov and Rechel 2007). In a similar vein Amagoh and Kabdiyeva (2012: 38) examined issues which could improve the sustainability of NGOs in Kazakhstan and concluded that while they are in a 'nascent state' NGOs have had 'positive results in elevating some issues of societal concerns to the public discourse, and persuading the government to take positive actions'. Kabdiyeva's research (2013) uncovered early signs of collaboration between the NGOs and the business sector. She saw significant potential for both parties in developing strategic partnerships. Saktaganova and Ospanova (2013: 1281) are even more sanguine when they claim that Kazakhstan NGOs are 'now beginning to operate to international standards' (see also Karzhaubayev and Sydykova, 2013). In a very balanced account of NGOs, with a specific focus on environmental groups, Soltys (2013) posed the research question as to whether they are 'the harbingers of the democratisation of the country that many observers hope to see?' Notwithstanding Soltys' description of Kazakhstan as a highly centralised corporatist state which 'is learning to share power only slowly', he sees some positive developments: 
The national government has liberalised its legislation on civic associations and has begun to allocate financial resources in support of NGOs' social activities and ENGOs' environmental ones. President Nazarbayev, the key figure in Kazakhstan's centralised political system, seems aware that certain kinds of social activism are both inevitable and desirable. Being personally secure in office and having a broader national view, he has instructed local executive officials to be more amenable to civic initiatives than these officials would have been otherwise (Soltys, 2013: 15).

Given the somewhat different assessments of the role of civil society in Kazakhstan from existing scholarship we consider additional evidence as a contribution to this ongoing debate.

\section{Methodology}

The data gathered for this study draws on empirical evidence from secondary sources and, in addition, reports the findings of qualitative research gathered through focus groups with NGOs in Kazakhstan. The focus of the data gathering linked directly to Crotty's operational definition referenced above. In both the primary and secondary research we looked for evidence of how civil society, using NGOs as medium for investigation, promoted democratic values, provided models of active citizenship, and tempered the power of the state. The secondary sources used were: World Bank Governance indicators; Freedom House monitoring data; USAID NGO sustainability index; data from the Bertelsmann Stiftung's Transformation Index; and, a Civicus study on civil society in Kazakhstan, all of which are described in more detail below.

Primary research was gathered through focus groups with NGOs. We categorised NGOs into their key areas of activities: environment; children and young people; women; medical; culture, arts, science and education; human rights; social welfare; community initiatives; disability and rehabilitation of children, and miscellaneous. We then invited representatives from across these sectors to attend focus groups and share their experiences of working in Kazakhstan on the three themes above (democracy, citizenship, and challenge function to the state) - see appendix 1 for details of organisations involved. Three focus groups were held in Astana during September/October 2013 with between 8-10 people in each group. There was no prior allocation to specific sessions but dates were offered to facilitate optimal attendance and to keep numbers in each group to a manageable level that would encourage debate and allow for a spread of opinion. The focus groups were co-facilitated by the authors and conducted in Russian and Kazakh. Not all sectors were equally represented and no claim is made here about the extrapolation of these qualitative data to NGOs as a whole - in short, this was a convenience sample (Bryman, 2008). Some of the organisations involved are relatively small-scale and localised. In an attempt to encourage frankness of opinions expressed, given the sensitivity of the subject under review, participants were guaranteed anonymity and there is no attribution of comments to individuals involved in 
the focus groups. Data were however recorded, transcribed and analysed using NVivo qualitative software which clustered the data broadly around the 3 thematic areas described above.

\section{The findings: secondary data}

There are a number of secondary empirical sources which offer some means of verifying Kazakhstan's journey towards democratisation. The World Bank, for example, reported on worldwide governance indicators for 215 economies over the period 1996-2012 along six dimensions: voice and accountability; political stability and absence of violence; government effectiveness; regulatory quality; rule of law; and control of corruption (Kaufmann, Kraay and Mastruzzi, 2010) $)^{1}$. The indicator of most relevance to this discussion is 'voice and accountability' which captures perceptions of the extent to which a country's citizens are able to participate in selecting their government, as well as freedom of expression, freedom of association and a free media.

\section{INSERT FIGURE 1 ABOUT HERE}

Figure 1 shows the percentile rank of each of the former Soviet countries neighbouring Kazakhstan. Percentile rank indicates the percentage of countries worldwide that rate below the selected CIS countries in figure 1. Higher values indicate better voice and accountability ratings. Hence, in the case of Kazakhstan, around $15 \%$ of 215 countries rate worse, or $85 \%$ rate better, than Kazakhstan on voice and accountability measures.

\section{INSERT FIGURE 2 ABOUT HERE}

If one looks at the trend in measurement of voice and accountability for Kazakhstan since 1996 (see figure 2) there is a small downward trajectory in the extent to which Kazakh citizens are able to participate in selecting their government, as well as freedom of expression, freedom of association and a free media. Compare this with another composite World Bank measurement on political stability and the absence of terrorism, defined by the likelihood that the government will be destabilized by unconstitutional or violent means, including terrorism, where the trend-line has been upwards until 2010 (since then there is a danger of unrest and destabilization in central Asian from the growing spread of radical Islamist ideas and also lack of cooperation between the region's countries). In light of these data, can civil society in Kazakhstan provide a bulwark against the excesses of a highly

\footnotetext{
${ }^{1}$ The World Bank aggregate indicators combine the views of a large number of enterprise, citizen and expert survey respondents in industrial and developing countries. The individual data sources underlying the aggregate indicators are drawn from a diverse variety of survey institutes, think tanks, non-governmental organisations, and international organisations.
} 
centralised and controlling regime where independent voice is limited and accountability remains weak?

Additional empirical evidence can be gleaned from Freedom House $^{2}$ data in the annual Nations in Transit reports (a comparative study of democratic development in 29 countries from Central Europe to Eurasia) which includes analyses of civil society in Kazakhstan. The 2011 report argued that the Presidential regime used its political influence to target burgeoning NGOs as a way of promoting social and infrastructural development, incorporating them into the system, rather than independent development. Progovernment NGOs receive public funding and are represented as working in partnership whereas independent groups are criticised as being 'irresponsible, serving outside interests, or opposing reforms and prosperity' (Dave, 2011: 271; see also Dave, 2007). Freedom House argued that the vast majority of NGOs are quasi-governmental groups who compete with 'real NGOs' in securing grants, and estimates that only 200 are able to make a positive impact. The report concludes:

Kazakhstan portrays itself as an open, tolerant, democratising state, committed to promoting civil society and non-governmental sector. In reality, the government has used the country's rising prosperity to enhance its international status, co-opt nascent NGOs into the state sphere, and constrain the development of an autonomous space where genuinely independent and self-organised associations and non-state actors can emerge (Dave, 2011: 265).

Agreeing with the broad thrust of these findings, Opposition leader Amirzhan Kosanov pointed out 'I would not assert unambiguously that we have no civil society. Probably it would be right to say that despite the authorities' reluctance to form a civil society and its endless efforts to make sure they fully control the process, the third sector is still emerging, albeit with difficulties' (Kosanov, 2010:3).

The most recent assessment by Freedom House points out the government of Kazakhstan has worked more aggressively to quash perceived threats to the regime since 2010' through recent legislation that impose harsh penalties on individuals who 'influence public and individual consciousness' through the distribution of 'unreliable' information 'to the detriment of national security' (Habdank-Kołaczkowska, 2013: 4).

To put some quantitative assessment on the status of civil society, and other indicators which Freedom House monitors, they allocate a yearly score on a rating system of 1 to 7 , with 1 representing the highest level of democratic progress and 7 the lowest. Scores reflect the consensus of Freedom House staff and academic advisors. The trend line in assessing the status of civil society in Kazakhstan from 2002 is shown in figure 3. In addition, United States Agency for International Development (USAID) compiles a yearly CSO sustainability

\footnotetext{
${ }^{2}$ Freedom House is an American based organisation which supports democratic change, monitors freedom, and advocates for democracy and human rights around the world.
} 
index which comprises seven dimensions: legal environment, organisation capacity, financial viability, advocacy, service provision, infrastructure, and public image (USAID, 2013). The index uses the same 7 point scale adopted by Freedom House with 1 indicating a very advanced NGO sector and 7 a low or poor level of development. In 2012, Kazakhstan scored an overall 4.1 against an average rating of 5.0 for Central Asian countries (which included: Kazakhstan, Kyrgyzstan, Tajikistan, Turkmenistan and Uzbekistan). Kyrgyzstan was the best performing country in Central Asia (with a score of 4.0) in terms of CSO sustainability. However the trend lines using both sets of indicators (Freedom House and USAID) show a static position of little or no improvement over the last decade. More recently (2012-13) Freedom House data suggest a worsening scenario for civil society in Kazakhstan (figure 3).

\section{INSERT FIGURE 3 ABOUT HERE}

The USAID sustainability report (2013) highlights several interesting findings. Few NGOs have strong support from their constituents, in part because some of them pursue issues that are not well known by the public and also because NGOs are not skilled enough in identifying and addressing constituency needs. Community needs tend to be identified by government and international donors, or NGOs in an unsystematic way. The level of state funding to NGOS is growing through ministries contracting services to be delivered but the mechanisms for this are ineffective. Social contracting is the main vehicle by which NGOs carry out service provision in areas such as social services, education and youth programming. NGOs mounted few advocacy campaigns and the lack of independence of the mass media hinders their efforts to do so (USAID, 2013). Freedom House assessment suggests a worsening situation for civil society in several Eurasian countries between 2011 2013 (see figure 4).

\section{INSERT FIGURE 4 ABOUT HERE}

If we replicate the countries appearing in figure 4 above (those Eurasian states with worsening civil society ratings) and consider Freedom House democracy scores on the same 1-7 scale, we can see that there is also a marginal deterioration in each, year on year (see figure 5).

\section{INSERT FIGURE 5 ABOUT HERE}

This prompted a further analysis on our part into the relationship between the two variables 'civil society' and 'democracy'. Using Freedom House scores on both variables, we looked at data over a 10 year period (2004-2013) for Kazakhstan and each of the former Soviet countries neighbouring Kazakhstan (i.e. those countries which appear in figure 1 above: Azerbaijan, Kazakhstan, Kyrgyzstan, Russia, Tajikistan Turkmenistan and Uzbekistan). The results of this analysis are set out in table 1 . The evidence shows a strong, positive 
correlation between the two variables $(r=.94, n=70, p<.0005)$ with high levels of democracy associated with high levels of civil society. This also raises the question prompted by Evers (2010) and Putnam, (1993) above: what is the direction of association here: does it take a strong civil society to make democracy work OR is the opposite true: does it take strong democracy to make civil society work?

\section{INSERT TABLE 1 ABOUT HERE}

Another source of empirical information of relevance is the Bertelsmann Stiftung's Transformation Index (BTI, 2012) which analyzes and evaluates the quality of democracy, movement towards a market economy, and political management in 128 developing and transition countries. It measures progress towards, or retreat from, democracy based on the rule of law and a socially responsible market economy. It does this through quantitative measures in three thematic areas: political management; economic transformation; and transformation management. Of interest to this paper are two research questions posed in the study: (a) to what extent are there traditions of civil society; and (b) to what extent does the political leadership enable the participation of civil society in the political process? A score of 1 represents the lowest value and 10 the highest value of political transformation. According to these data, Kazakhstan has a relatively strong tradition of civil society but a weak record of leaders enabling participation of civil society in the political process (see table 2).

\section{INSERT TABLE 2 ABOUT HERE}

Finally, in terms of secondary quantitative data, a more holistic source of empirical information on civil society in Kazakhstan is offered by Civicus which uses a combination of participatory and scientific research methods to generate an index that summarises five core dimensions of civil society (civic engagement, level of organisation, practice of values, perception of impact, and the external environment of civil society). The results of their assessment on these dimensions are shown in figure 6 . Civicus concluded that the civil society diamond is one of a 'moderately developed Kazakhstan civil society' (Makhmutova and Akhmetova, 2011: 9).

\section{INSERT FIGURE 6 ABOUT HERE}

The report offers more detailed analysis of each of the 5 dimensions as follows:

- Civic engagement (46.9\%) suggests that citizen participation in Kazakhstan is characterised by more extensive and deeper socially based engagement than politically-based engagement. 
- The level of organisation (48.4\%) shows that civil society organisations operate within a relatively well developed framework of infrastructure and resources although this is inhibited by its reliance on a small and often unsustainable human resource base.

- The practice of values $(47.6 \%)$ showed that the most consistently practiced values within civil society are those of democratic decision-making, non-violence, equal gender opportunities, peace and tolerance, but civil society did not practice values of anti-corruption.

- The perception of impact (40\%), the lowest score of all dimensions, indicated that those inside and outside civil society agreed that it had a more limited impact on influencing policy than on affecting change in a range of social fields.

- The external environment (46.5\%) found significant challenges facing civil society, including high levels of corruption, limited political rights and personal freedoms, and significant constraints on the rule of law and state effectiveness

(Civicus, Civil Society Index 2011).

The Civicus report concluded that the overall picture of civil society in Kazakhstan is 'a cautiously optimistic one' where there are enough positive strengths to build on but there needs to be a 'real focus and commitment from government, civil society and the donor community if the considerable weaknesses of civil society are to be overcome' (Makhmutova and Akhmetova, 2011: 53).

Having considered the secondary quantitative data, we turn to qualitative data gathered from NGO activists in Kazakhstan.

\section{The findings: primary data}

The focus groups session with NGOs participants were analysed under three board headings arising from the definition adopted for this research (promoting democratic values; providing models of active citizenship; and moderating the power of the state). We discuss each of these in sequence.

\section{(a) Promoting democratic values}

Participants in the focus groups thought that while promoting democratic values may be a laudable goal, it did not particularly fit the context of Kazakhstan and was more apposite to a Western perspective on the role of NGOs. Kazakhstan, they argued, was still a relatively 'young' country following independence and needed an incremental approach to democracy. Several participants questioned what precisely was meant by 'democratic values' insisting that Kazakhstan held elections, implemented the rule of law, had a growing 
economy, positive socio-economic indicators and stable government institutions (Ministries). What 'additionally was required', they asked, and what could NGOs do to help achieve these 'democratic values'. As one participant noted:

Kazakhs are a proud people with a rich history of self-help and strong family ties. To suggest that we should aspire to some model of democracy that ignores our heritage is like giving a small child unpleasant medicine and telling her it will be good for her. We have not experienced these 'democratic values' that you imply will be good for us and which ignores our previous 'medical record'!

This led to a discussion of the role of international NGOs in Kazakhstan. Some participants from local NGOs were suspicious of the motives of internationally funded NGOs. Whilst grateful for the funding which they invested in Kazakhstan and the help afforded to vulnerable people in the field of welfare services, some questioned their ulterior intentions. This was captured by the comment:

Are they here first and foremost to help a developing country and, in turn, to evangelise to us about how we should reform to comply with how their countries operate. What, for example, has the UK or USA to teach us about ethnic co-operation when we look at racism in these countries?

Examples were offered that illustrated the 'fear of government' towards international NGOs which had, or wanted to have, a presence in Kazakhstan. Licensing and operational rules were constantly being tightened to restrict the entry of international NGOs or limit their activities for those which were already in-country. They have to sign agreements about the nature of their work, where their funding is derived, and adhere to strict lines of accountability to the relevant ministry. In espousing 'talk about human rights and democratic values' the fear is that international NGOs could mobilise people against the state which would result in social unrest in a country which prides itself on multi-ethnic stability. Given the ethnic demographics of Kazakhstan, this could create volatility where Russians have a significant presence.

The issue for the Government of Kazakhstan is that we want to raise our democratic profile on the international stage with developed countries. One aspect of international respectability is to show the existence of a well-developed civil society. The Government put in place a programme (Development of Civil Society 2006-11) to assist in achieving this with associated indicators of performance. Problem is that we missed the targets set and hence state-NGOs were established, some of which were no more than an address and email to present a front or shop window to the outside world.

There was however a clear acknowledgement of, and welcome for, the expertise that international donors could offer in capacity building for Kazakh NGOs which were under- 
resourced and lacked training in core areas of services delivery. Moreover, participants accepted that external funding allowed NGOs greater freedom of expression and less reliance on Ministries and government organisations in Kazakhstan.

\section{(b) Providing models of active citizenship}

Concepts such as 'active citizenship' were not fully understood by focus group participants. They did however characterise Kazakh people as being 'passive citizens under Soviet rule' because of the dominant role played by the State in their lives. With such a recent history of State pervasiveness it had proved difficult for NGOs in Kazakhstan to encourage volunteerism and persuade people to take a more active role in society. As one participant described it:

This was a whole new approach for us - getting people involved in organising activities for their communities was alien to us. We were used to a top-down model underpinned by a strong network of kinship and family support. At first we were challenged to take control of our own communities through a self-help model assisted financially by government in the form of grants.

Focus group participants claimed that over the last 10-year period there has been a significant shift in the attitude of government to NGOs. In 2005, for example, a new law 'State Social Bid' (literal translation, which means the commissioning of social services from NGOs) created a new operating environment for NGOs and was the start of a period or partnership working with state organs. This development was consolidated further through the 'Civil Society Development Concept' in 2006 which improved the legal, economic and organisational milieu for NGOs drawing directly on international standards to inform the Concept. One of the core objectives of the Concept is 'to establish harmonious and equitable partnerships between governmental organisations, the business sector and NGOs'. The Concept also included economic incentives for the business sector to collaborate with NGOs.

There were dissenting voices amongst focus group participants, however. The state-led NGOs have been a convenient mechanism for government to shift public services delivery into the third sector. This has had two results. First, ministries can blame NGOs when services fall below quality standards which, in part, can be because of poor funding from government. Second, increasing the number of state-led NGOs allows for an increased in their number adding to Kazakhstan's public image of a country with a growing civil society. As one contributor described it:

There is no challenge coming from the NGO sector to government. State-NGOs are an integral part of our public service delivery machinery. They also provide an opportunity for corruption. State officials can skim-off funding to state-NGOs through contract procedures. The same is true of independent NGOs. If you want to 
survive as an organisation, then you pay officials. Funding is the key way of controlling the sector. Everyone knows this - it is part of Kazakhstan mentality. We all understand not to bite the hand that feeds us. Conflict and dissent are discouraged because it will have funding implications. To 'rock the boat' is to contribute to your own demise - stay below the radar and you get a monthly salary. Agitate and you lose your source of income. There is no choice for me.

NGOs simply reflect the wider environment in which they work - corruption is rife, nepotism is the order of the day, ministries are all-powerful in the survival of independent NGOs. The unspoken 'agreement' is to acquiesce in the status quo or risk your continued existence as an organisation. The system becomes self-perpetuating as a result.

One suggestion from participants which attracted significant support amongst NGOs was the wider political imperative towards decentralisation of public services. This idea was described as follows:

The Government has been keen to promote self-government through greater decentralisation. So far this has not been very successful. People are not yet ready for this development. Local NGO development could help achieve this goal. If public services can be provided through a partnership approach between the state and NGOs, then this could stimulate the idea of local government which the authorities are keen to endorse. This is why I think there is more funding going into the NGO sector. The government now recognises how well NGOs understand local need and can respond more effectively to it, as opposed to the detached nature of some of our Ministries and Akimats.

The nature of state-society relations has therefore moved on significantly in recent years, participants claimed. Government increasingly see NGOs are 'partners' in service provision and are prepared to increase grants available to them to deliver welfare/social services given their closeness to the point of delivery and understanding of local needs.

\section{(c) Moderating the power of the state}

The language used in this thematic area was again quite alien to NGO participants. They did not see their primary role as 'challenging the state' and preferred to think of it as a partnership model in which they felt comfortable expressing alternative opinions and views which may or may not be accepted. As an example of this development, several cited the Community Commission ${ }^{3}$ which is a forum chaired by officials from the Office of the

\footnotetext{
3 The Commission included the following groups (in Russian): Экспертные советы при местных исполнительных органах", “Координационный совет по взаимодействию с неправительственными организациями при Правительстве Республики Казахстан”, “Экспертный Совет Комиссии по правам человека при Президенте РК ", “Общественная палата при Мажилисе Парламента РК ", “Общественные и консультативные советы при всех министерствах и агентствах"
} 
President to seek the views of NGOs. It acted as a 'sounding board' for Government and allowed NGOs to promote ideas for new legislation or make amendments to existing laws and policies. One participant offered the following example:

There have been major reforms in the senior civil service in Kazakhstan where top officials are divided into two cadres (Corps A and Corps B). As a measure of the influence of NGOs, some of us are now involved in the recruitment process for Corps A civil servants. This gives you an indication that our sphere of influence has increased significantly. In the Community Commission we continuously push for greater transparency in public services through our involvement in the current reforms on performance management.

Each of the Ministries has its own consultation forum in which relevant NGOs participate and it acts as a platform for ideas or new initiatives. In addition, yearly civil forums (Гражданский Форум) are held as showcase events and are opened by the President of Kazakhstan. An Alliance of NGOs (Гражданский Альянс) now operates as an umbrella group for more than 500 active NGOs. Notwithstanding these collaborative activities, NGOs continue to lobby for change through their contacts in Parliament, the media, and through research and advocacy work. Kazakh people cultivate personal networks through family and clan connections and therefore lobbying is somewhat different than in Western societies. Typically NGOs will lobby for additional funding, training resources and capacity building in the sector, legislative changes, and the need for a greater number of NGOs in the fields of disability and social welfare.

Several focus group participants dissented from this view of the 'partnership model' as outlined above. They considered the actions of government to be opaque, impervious to ideas coming from the NGO sector, and repressive in their actions towards them. As one contributor pointed out:

We do not have a partnership with government as this implies an equal relationship with the state. We don't have that. To the outside observer, it appears that civil society works well with government. In fact, this relationship is controlled by financial support from government. If you don't comply, you don't receive government funds. Simple as that. Without government funding many of us could not exist. With limited funding there are no resources to develop professional capacity in NGOs and hence the quality of our organisations is low. It's a vicious circle.

Some participants claimed that the legislation on civil society is unclear which results in different interpretations being applied across ministries. They called for new legislation similar to that which exists in Russia as a way to protect them against the excesses of government and clarification on their rights under the law. 
In summary, Kazakhstan NGOs are being better funded by government which could limit any potential 'challenge' function. Some see the evolving relationship as a dynamic and growing partnership with government in which there are mutual benefits and their influence is increasing, although there was no consent on this position. The long term goal of NGOs is to mobilise Kazakh people to play a much more active role in society and to become much less reliant on the state.

\section{Conclusions}

In reaching some conclusions to this paper we return to the research question posed at the outset: has the asymmetric state-society relationship evident from the Kazakhstan's independence in 1991 shifted in favour of a stronger societal voice through a more vibrant civil society? This research has clearly identified shortcomings in trying to address this question, not least definitional issues. It has proved difficult to circumscribe civil society in Kazakhstan and our attempts to operationalise this through the narrower lens of examining NGOs has not been easy given the interchangeably of the terminology used by government officials and fuzziness of the boundaries. Our work offers a much more nuanced conclusion to the polemic that that there are two contrary views held about Kazakhstan: that civil society is a strong and influential actor; and, that civil society is embryonic (Makhmutova and Akhmetova, 2011). We suggest that civil society in neither embryonic or strong and influential but importantly the fulcrum of state society relations is shifting towards a stronger societal voice through the work of NGOs. It is easy to see how, examined from the perspective of liberal democracies, one could conclude that civil society in Kazakhstan falls short of the operational definition used to structure this paper: promoting democratic values; providing models of active citizenship; and, moderating the power of the state. This however fails to fully appreciate the Soviet heritage of Kazakhstan and the cultural mentality of kinship, clan, extended family and self-reliance, synonymous with Kazakh society. International NGOs fail to understand these significant cultural factors. Nezhina and Ibrayeva (2013:356), for example, conclude in their research that 'NGOs inspired by Western donors are currently ineffective in Kazakhstan'.

The evidence gathered in this study is mixed. The Civicus data are more sanguine than other empirical assessments which suggest a static or declining role played by civil society as a bulwark against a highly centralised and controlling state. Research by Kazakh scholars and NGO workers in this paper, on balance, tend to be more positive about recent legislative and funding changes in favour of a growing and stronger sector. There also appears to be a level of optimism about the future potential of NGOs now that they have been endorsed by the President and are working collaboratively with Ministries. None of this is to deny real problems in the operating environment of NGOs about which a number of our focus group participants spoke at length. We heard claims from one NGO in our focus groups that where NGOs compete for social contracts, the allocation process is opaque, corruption is 
pervasive, technical specifications are written in a way which prevents competition, and conditions of offer are replete with language that appeals for the 'promotion of patriotism' and the necessity of 'establishing a positive image of Kazakhstan". That said, NGOs provided evidence of much greater interaction between state organs and the nongovernmental sector both in the delivery of contracted public services and direct participation on key consultation and decision making fora. This growing 'partnership' has been bolstered by a supportive legislative framework and greater levels of public funding available to NGOs which are increasingly operating in the field of social welfare as an agent of Government. All of this might simply illustrate two points made by Aarts and Cavatorta (2013: 8-9) that: (a) the combination of repression and co-optation by authoritarian regimes have guaranteed political stability and (b) the unquestioned acceptance of authoritarian frameworks by civil society has lowered expectations of changes - the status quo prevails and is unlikely to change. Participants in this study were clearly resigned, although in some cases grudgingly, to this conclusion. 


\section{Appendix 1: Sample list of NGOs in Kazakhstan}

\begin{tabular}{|c|c|}
\hline $\begin{array}{c}\text { Primary activity } \\
\text { of NGO }\end{array}$ & List of Targeted local and international NGOs \\
\hline Environment & $\begin{array}{l}\text { - } \quad \text { ECO - Mangistau } \\
\text { - Public Fund (EcolDEA) - Development Agency of Environmental Initiatives } \\
\text { - } \quad \text { The Canadian Cooperation Fund on Climate Change }\end{array}$ \\
\hline $\begin{array}{l}\text { Children and young } \\
\text { people }\end{array}$ & $\begin{array}{ll}\text { - } & \text { PF Regional Center Junior Achievement } \\
\text { - } & \text { NGO Youth Center Leaders of the } 21^{\text {st }} \text { Century } \\
\text { - } & \text { Representation of the World Assembly of Muslim Youth } \\
\text { - } & \text { UN Children's Fund (UNICEF) }\end{array}$ \\
\hline Women & $\begin{array}{l}\text { - } \text { Women's Federation } \\
\text { - } \quad \text { Association of Business Women of Kazakhstan } \\
\text { - } \quad \text { Development Fund for Women }\end{array}$ \\
\hline Medical & $\begin{array}{l}\text { - } \quad \text { Kazakhstan Association on Sexual and Reproductive Health (KMPA) } \\
\text { - } \quad \text { The Red Crescent Society of Kazakhstan } \\
\text { - } \quad \text { Korean Oriental Medicine Service Abroad } \\
\text { - } \quad \text { The Global Fund to Fight AIDS, Tuberculosis and Malaria }\end{array}$ \\
\hline $\begin{array}{l}\text { Culture, arts, } \\
\text { science and } \\
\text { education }\end{array}$ & $\begin{array}{l}\text { - } \text { RNOO Association of Young Scientists } \\
\text { - } \quad \text { PF Revival Ethno Culture } \\
\text { - Hanns Seidel Foundation } \\
\text { - } \quad \text { Soros - Kazakhstan } \\
\end{array}$ \\
\hline Human rights & $\begin{array}{l}\text { - } \quad \text { Public Foundation 'Charter for Human Rights' } \\
\text { - } \quad \text { Legal Assistance for Veterans and Pensioners }\end{array}$ \\
\hline Social welfare & $\begin{array}{l}\text { - } \quad \text { Center for Protection of Motherhood and Childhood (Zhanuya) } \\
\text { - } \quad \text { Dana" Center of Social Support for Families } \\
\text { - Public fund charitable organization "Social Reform" } \\
\text { - } \quad \text { Economic and Social Commission for Asia and the Pacific (ESCAP/ ESCAP) }\end{array}$ \\
\hline $\begin{array}{l}\text { Community } \\
\text { initiatives }\end{array}$ & $\begin{array}{l}\text { - } \quad \text { Center for promotion of Legal and Social Development } \\
\text { - } \quad \text { ALE Almaty Association of Entrepreneurs } \\
\text { - } \quad \text { Canadian Local Initiative Program }\end{array}$ \\
\hline $\begin{array}{l}\text { Disability and } \\
\text { rehabilitation of } \\
\text { children }\end{array}$ & $\begin{array}{l}\text { - OO «Obshchestvo detey-invalidov g. Astana» Sotsial'naya pomoshch', prava } \\
\text { detey-invalidov OO «Tsentr sotsial'noy adaptatsii detey» Okazaniye } \\
\text { psikhologomediko - pedagogicheskoy i pravovoy pomoshchi detyam s } \\
\text { ogranichennymi vozmozhnostyami } \\
\text { - Society of Disabled Children in Astana } \\
\text { - Center for Social Adaptation of Children }\end{array}$ \\
\hline Miscellaneous & - AF Union of Journalists of Kazakhstan \\
\hline
\end{tabular}




\section{References}

Aarts, P. and Cavatorta, F. eds. (2013) Civil Society in Syria and Iran: Activism in Authoritarian Contexts (2013), Boulder, Co: Lynne Rienner Publishers

Amagoh, F. (2011) 'New Public Management and Health Reform in Kazakhstan' International Journal of Public Administration, 34: 567-578.

Amagoh, F. and Kabdiyeva, A. (2012) 'Management Issues for Improving NGO Sustainability in Kazakhstan' World Journal of Social Sciences 2 (3): 31 - 40

Amnesty International (2013) Old Habits: the routine use of torture and other ill-treatment in Kazakhstan. Eur 57/001/2013. London: Amnesty International.

Asanova, J. and Sedova, T. (2013) 'Kazakhstan' in CSO Sustainability Index for Central and Eastern Europe and Eurasia, $16^{\text {th }}$ edition: 95 - 101 Washington: USAID

Bertelsmann Stiftung's Transformation Index (BTI) (2012) Transformation Index BTI 2012: Political Management in International Comparison. Gütersioh: Verlag Bertelsmann Stiftung.

Bhuiyan, S. and Amagoh, F. (2011) 'Public sector reform in Kazakhstan: issues and perspectives' International Journal of Public Sector Management 24 (3): 227-249.

Bhuiyan, S. (2012) 'Political Leadership and its Role in Achieving Good Governance in Kazakhstan' International Journal of Public Administration, 35 (6): 379-388.

Brumberg, D. (2002) 'The trap of liberalized autocracy', Journal of Democracy, 13 (4): 56-68.

Bryman, A. (2008) Social Research Methods ( $3^{\text {rd }}$ ed.) Oxford: Oxford University Press.

Buxton, C. (2011) The Struggle for Civil Society in Central Asia: crisis and transformation, Sterling VA: Kumarian Press.

Candland, C. "Civil Society" (2001) The Oxford Companion to the Politics of the World, 2e. Joel Krieger, ed. Oxford University Press Inc. 2001.

Cavatorta, F. and V. Durac (2011) Civil Society and Democratization in the Arab World: the dynamics of activitism. London: Routledge.

Civicus (2011) Strengthening Civil Society Civicus Civil Society Index 2008 - 2010. Almaty: Civicus and Public Policy Research Centre (PPRC).

Corke, S. (2012) 'Kazakhstan: as stable as its Government claims?' Testimony of Director of Eurasia Programs, Freedom House before the US Commission on Security and Cooperation in Europe, $25^{\text {th }}$ January. 
Crotty, J. (2009) 'Making a difference? NGOs and civil society development in Russia', Europe-Asia Studies 61 (1): 85-108

Cummings, S.N. (2001) 'Kazakhstan: An Uneasy Relationship - Power and Authority in the Nazarbaev Regime', in Cummings S.N (ed.), Power and Change in Central Asia, pp. 59-73. London and New York: Routledge.

Cummings, S.N. (2002) Kazakhstan: power and the elite. London: I.B. Tauris.

Cummings, S. N. and Ryabkov, M. (2008) 'Situating the 'Tulip Revolution", Central Asian survey, 27 (3-4): 241-252.

Cummings, S.N. (2012) Understanding Central Asia: politics and contested transformations. London: Routledge.

Daucé, F. (2014) 'The government and human rights groups in Russia: civilized oppression' Journal of Civil Society, 10 (3): 239-254.

Dave, B. (2007) Kazakhstan: Ethnicity, Language and Power. London: Routledge.

Dave, B. (2011) 'Kazakhstan' in Nations in Transit 2011. Washington: Freedom House.

Deakin, N. (2001) In Search of Civil Society. Basingstoke: Palgrave

Evers. A. (2010) 'Observations on Incivility: blind spots in third sector research and policy' Voluntary Sector Review 1 (1): 113-17

Ernst and Young (2013) EY's Attractiveness Survey: Kazakhstan 2013 - Unlocking Value. London: Ernst and Young.

Foley, M.W. and Edwards B. (1996) 'The paradox of civil society'. Journal of Democracy 7, 38-52

Freedom House (2013) Nations in Transit: Authoritarian Aggression and the Pressures of Austerity. Washington: Freedom House.

Froissart, C. (2014a) 'The ambiguities between contention and political participation: a study of civil society development in authoritarian regimes', Journal of Civil Society, 10 (3): 219222.

Froissart, C. (2014b) 'Using the law as a 'harmonious weapon': the ambiguities of legal activism in favour of migrant workers in China' Journal of Civil Society, 10 (3): 255-272.

Geoffray, M. L. (2014) 'Channelling protest in illiberal regimes: the Cuban case since the fall of the Berlin wall' Journal of Civil Society, 10 (3): 223-238. 
Habdank-Kołaczkowska, S. (2013) in Nations in Transit: Authoritarian Aggression and the Pressures of Austerity. Washington: Freedom House

Huseyin, S. (2003) Unmaking of Political Public Sphere: State and Civil Society in Kazakhstan. University of Idaho: PhD Dissertation.

Idrissov, E. (2013) 'Democracy will come to Kazakhstan - Kazakh Foreign Minister'. Interfax: Central Asia \& Caucasus Business Weekly: $5^{\text {th }}$ February.

International Monetary Fund (2014) Kazakhstan Country Reports: http://www.imf.org/external/country/KAZ/index.htm accessed 8th January 2014.

Isaacs, R. (2010) 'Informal politics and the uncertain context of transition: revisiting early stage non-democratic development in Kazakhstan', Democratization, 17 (1): 1-25.

Jensen, M. (2006) 'Concept and conceptions of civil society' Journal of Civil Society 2, 39-56.

Kabdiyeva, A. (2013) 'Collaboration of NGOs and Business in Kazakhstan' European Journal of Business and Social Sciences, 2 (1): 99-109

Karzhaubayev, E. K. and Sydykova A. E. (2013) 'State and Civil Society Institutes interaction in the Republic of Kazakhstan', Middle-East Journal of Scientific Research 14 (4): 516-524

Kaufmann, D., Kraay, A. and Mastruzzi M. (2010) The Worldwide Governance Indicators. Washington DC: World Bank.

Kazakhstan Agency of Statistics (2014) www.acorda.kz accessed $8^{\text {th }}$ January 2014

Keane, J. (2009) 'Civil Society, Definitions and Approaches' in H. Anheier and S. Toepler (eds) International Encyclopaedia of Civil Society pp. 461-464 New York: Springer-Verlag.

Kelly, I. (2013), US Ambassador to the Permanent Council of OSCE, cited in Nicol, J. (2013) Kazakhstan: recent developments and U.S. Interests. Congressional Research Service 7-5700. Washington D.C.

Kuchukeeva, A.and O'Loughlin, J. (2003) 'Civic Engagement and Democratic Consolidation in Kyrgyzstan', Eurasian Geography and Economics, 44 (8): 557-87.

Kosanov, A. (2010) 'Kazakh Opposition leader calls for parliamentary rule', $29^{\text {th }}$ December 2010. BBC Worldwide Monitoring.

Kubicek, P. (1998) 'Authoritarianism in Central Asia: curse or cure?' Third World Quarterly: 19 (1): 29-43 
Kulzhanov, M. and Rechel, B. (2007). 'Kazakhstan: Health system overview'. In B. Rechel (Ed.), Health systems in transition. Geneva: European Observatory on Health Systems and Policies.

Lewis, D. (2009) Nongovernmental Organizations, Definition and History in H. Anheier and S. Toepler (eds) International Encyclopaedia of Civil Society New York: Springer-Verlag .

Lidauer, M. (2012) 'Democratic dawn? Civil society and elections in Myanmar 2010-2012' Journal of Current Southeast Asian Affairs 2: 87-114.

Ljubownikow, S., Crotty, J. and Rodgers, P.W. (2013) The state and civil society in PostSoviet Russia: The development of a Russian-style civil society Progress in Development Studies 13 (2):153-166

Luong, P.J. and Weinthal, E. (1999) The NGO paradox: Democratic goals and non-democratic outcomes in Kazakhstan. Europe-Asia Studies 51 (7): 1267-84.

Makhmutova, M. and Akhmetova, A. (2011) Civil Society Index in Kazakhstan Strengthening Civil Society Civicus Civil Society Index 2008 - 2010. Almaty: Civicus and Public Policy Research Centre (PPRC).

Matakbaeva, L. (2013) 'Mechanisms of political authority legitimation in Republic of Kazakhstan' Life Science Journal, 10 (12): 510-517.

Ministry of Culture and Information, Kazakhstan http://en.government.kz/structure/org/m06 accessed $8^{\text {th }}$ January 2014

Moscow News (2012) 'Kazakhstan massacre death toll may rise to 200'. 14 ${ }^{\text {th }}$ February 2012.

Nazarbayev, N. (2011) 'Kazakhstan's democratic destiny' The Washington Post $1^{\text {st }}$ April: A17.

Nezhina, T. G. and Ibrayeva, A. R. (2013) 'Explaining the role of culture and traditions in functioning of Civil Society Organizations in Kazakhstan' Voluntas 24:335-358

Nicol, J. (2013) Kazakhstan: recent developments and U.S. Interests. Congressional Research Service 7-5700. Washington D.C.

Organisation for Security and Co-operation in Europe (2011) Republic of Kazakhstan: early Presidential Election. OSCE/ODIHR Election Observation Mission Final Report.

Organisation of Security and Co-operation in Europe (2012) Republic of Kazakhstan: early Parliamentary Elections. Warsaw: OSCE/ODIHR Election Observation Mission Final Report .

Ovcharenko, V. (2004) 'The state-civil society relationship in Kazakhstan: mechanisms of cooperation and support' The International Journal of Not-for-Profit Law, 6 (3). 
Putnam, R. D. (1993): Making Democracy Work. Princeton: Princeton University Press

Rivetti, P. and Cavatorta, F. (2013) 'The Importance of being Civil Society': student politics and the reformist movement in Khatami's Iran' Middle Eastern Studies 49 (4): 645-660.

Saktaganova, Z. G. and Ospanova, D. K. (2013) 'Non-Governmental Organisations in the Republic of Kazakhstan: principal stages of formation and development' Middle-East Journal of Scientific Research 15 (9): 1277 - 1284.

Schatz, E. (2009) 'The soft authoritarian tool kit: agenda-setting power in Kazakhstan and Kyrgyzstan', Comparative Politics, 41 (2): 203-222.

Schatz, E. and Maltseva, E. (2012) 'Kazakhstan's Authoritarian "Persuasion"' Post - Soviet Affairs 28 (1): 45-65.

Schmidt, M. (2013) 'No end to transformation? Central Asia between post-socialism and globalization. Geographische Rundschau, 65 (11): 4-10.

Shine, K-Y (2012) 'The dilemmas of Korea's new democracy in an age of neoliberal globalisation' Third World Quarterly 33 (2): 293-309.

Silitski, V. (2010) 'Survival of the fittest': Domestic and international dimensions of the authoritarian reaction in the former Soviet Union following the colored revolutions Communist and Post-Communist Studies 43: 339-350.

Soltys, D (2013) 'Challenges to the Institutionalisation of Environmental NGOs in Kazakhstan's Corporatist Policy Arena' Journal of Contemporary Asia.

DOI: 10.1080/00472336.2013.848314.

Strecansky, B. (2012) 'The situation of the third sector in Slovakia - the impact of crisis: trends, mainstreams and challenges' Civil Szemle 9 (3): 95-114

United States Agency for International Development (USAID, 2013) CSO Sustainability Index for Central and Eastern Europe and Eurasia, $16^{\text {th }}$ edition. Washington: USAID.

World Bank (2013) World Bank Group - Kazakhstan Partnership Program Snapshot. Astana: World Bank Offices.

World Bank (2014) World Bank Economic Indicators http://www.worldbank.org/en/country/kazakhstan/overview accessed $12^{\text {th }}$ December 2013

Ziegler, C. (2010) 'Civil society, political stability, and state power in Central Asia: cooperation and contestation' Democratization 17 (5): 795-825. 


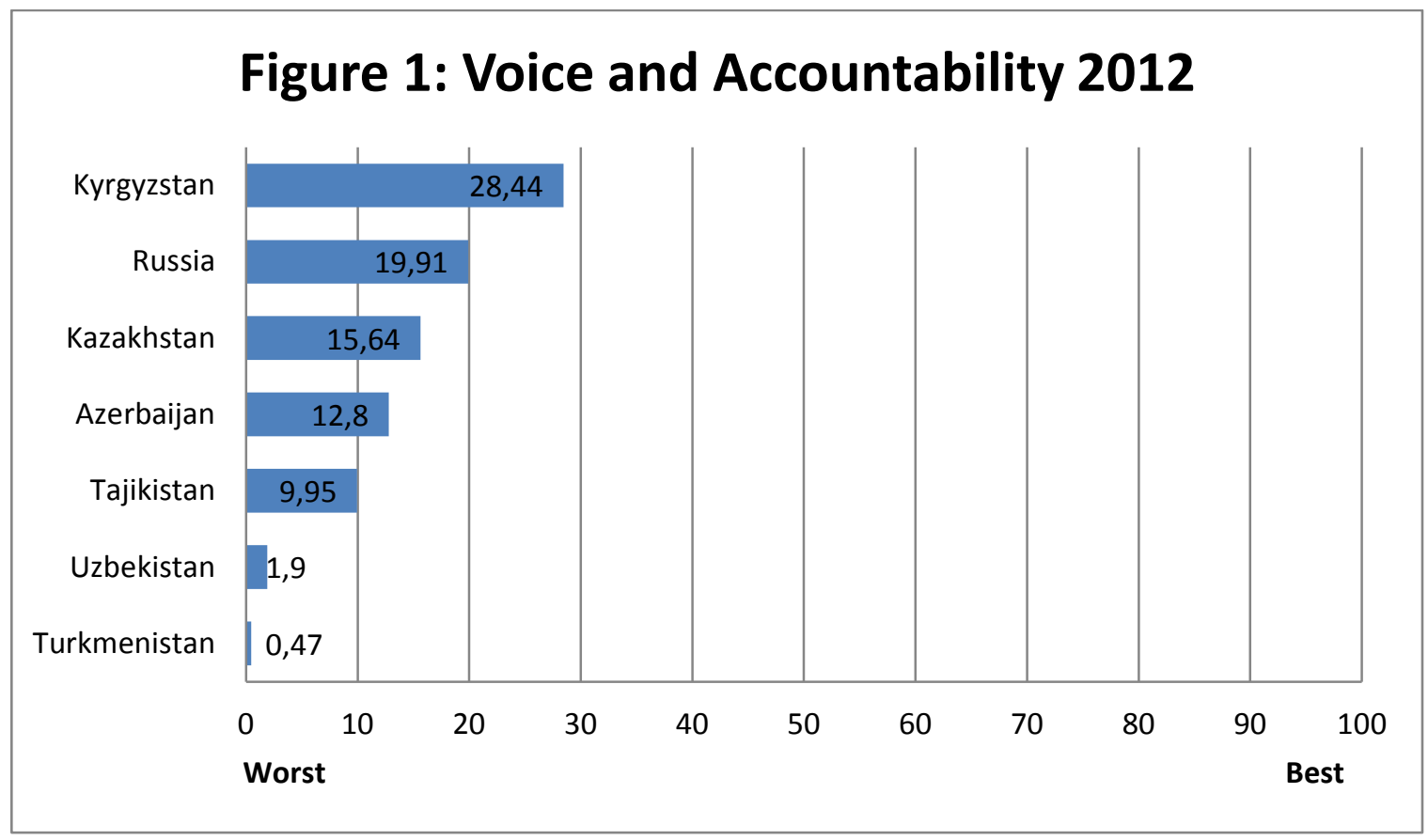

Source: Calculated from World Bank Group - Worldwide Governance Indicators 


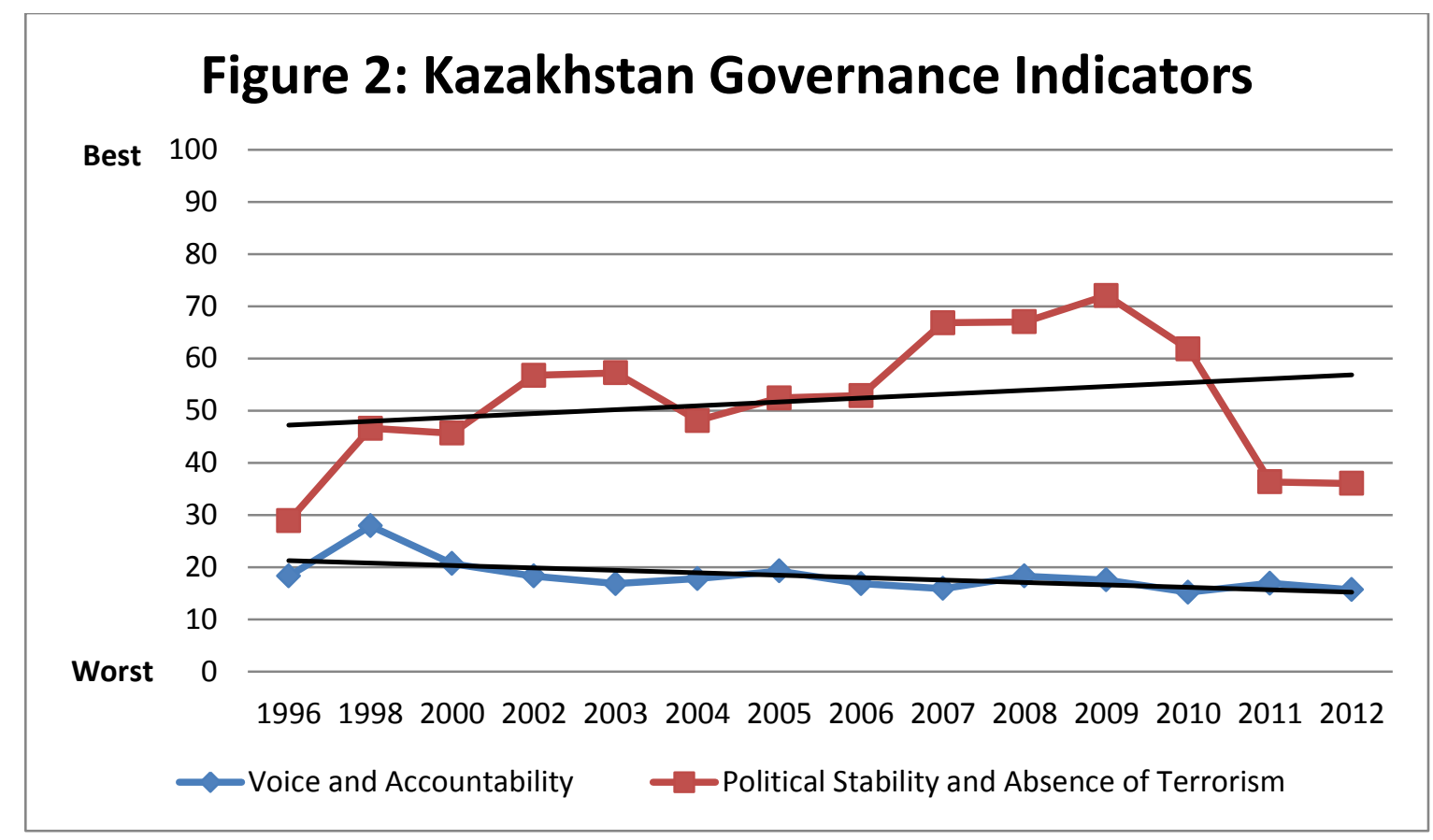

Source: Calculated from World Bank Group - Worldwide Governance Indicators (1996-2012) 


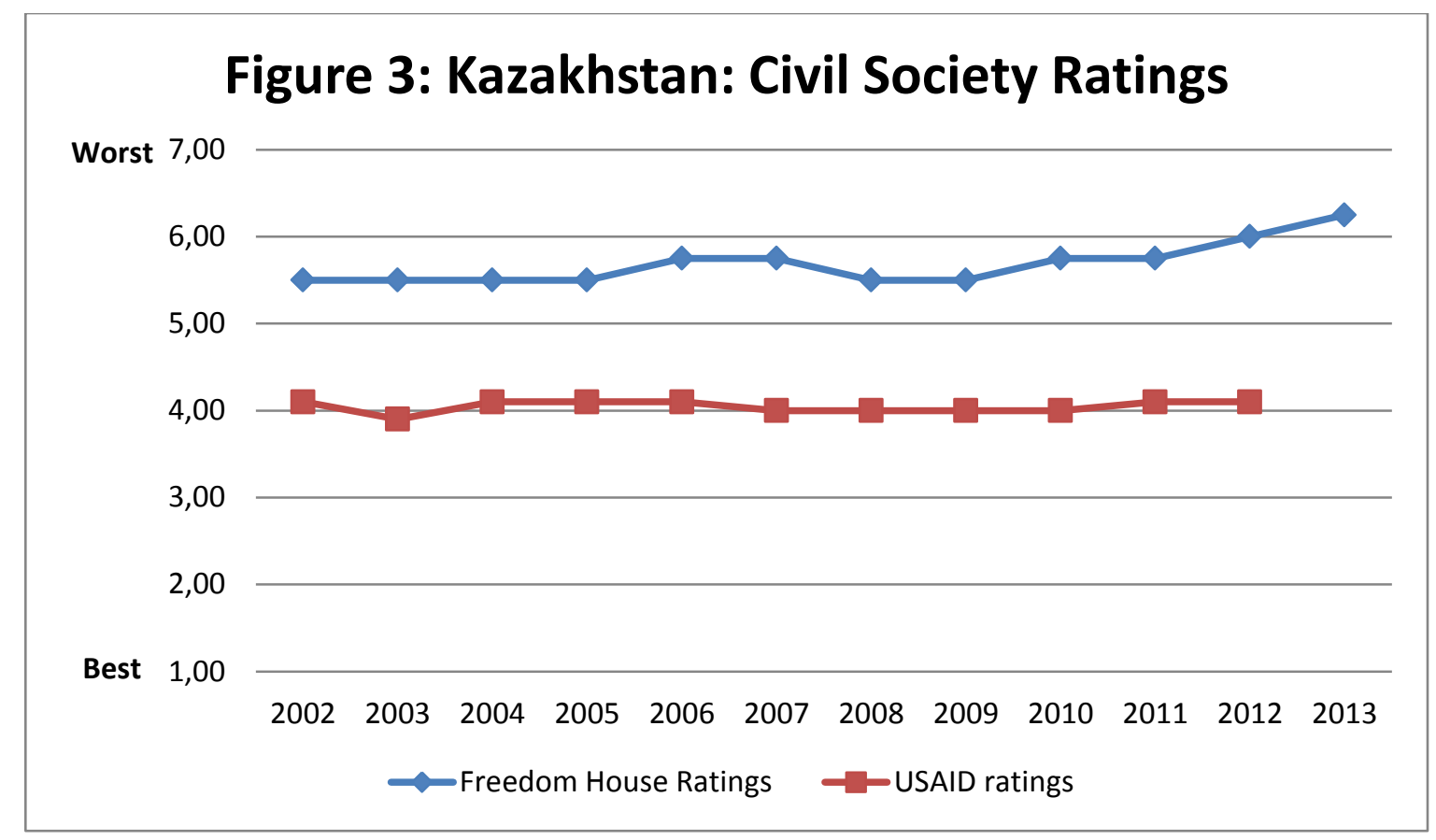

Sources: Calculated from Freedom House Nations in Transit (2013) Civil Society in Kazakhstan and United States Agency for International Development (2012) CSO Sustainability Index for Central and Eastern Europe and Eurasia, $16^{\text {th }}$ edition. 


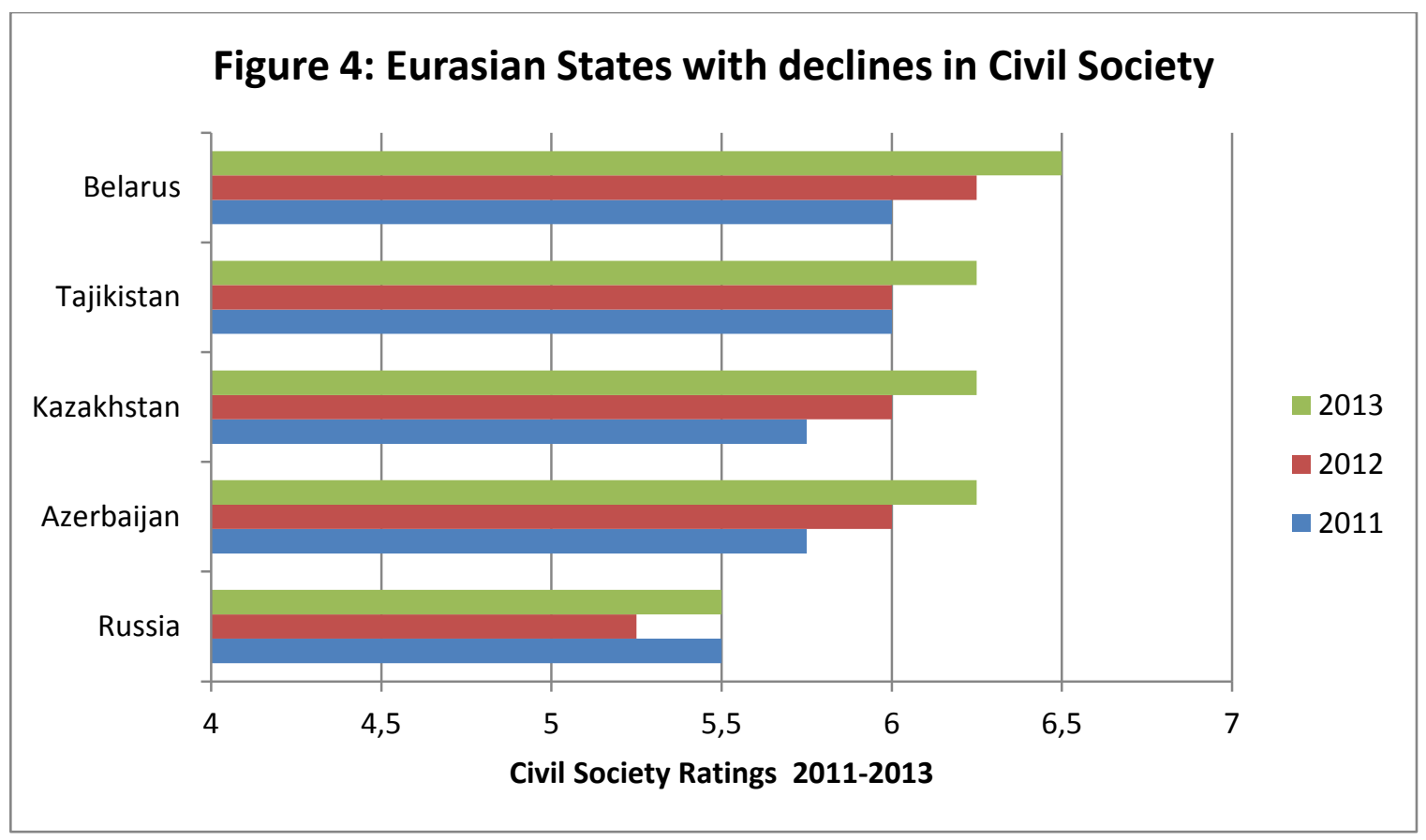

Source: Calculated from Nations in Transit data, Freedom House (2013) 


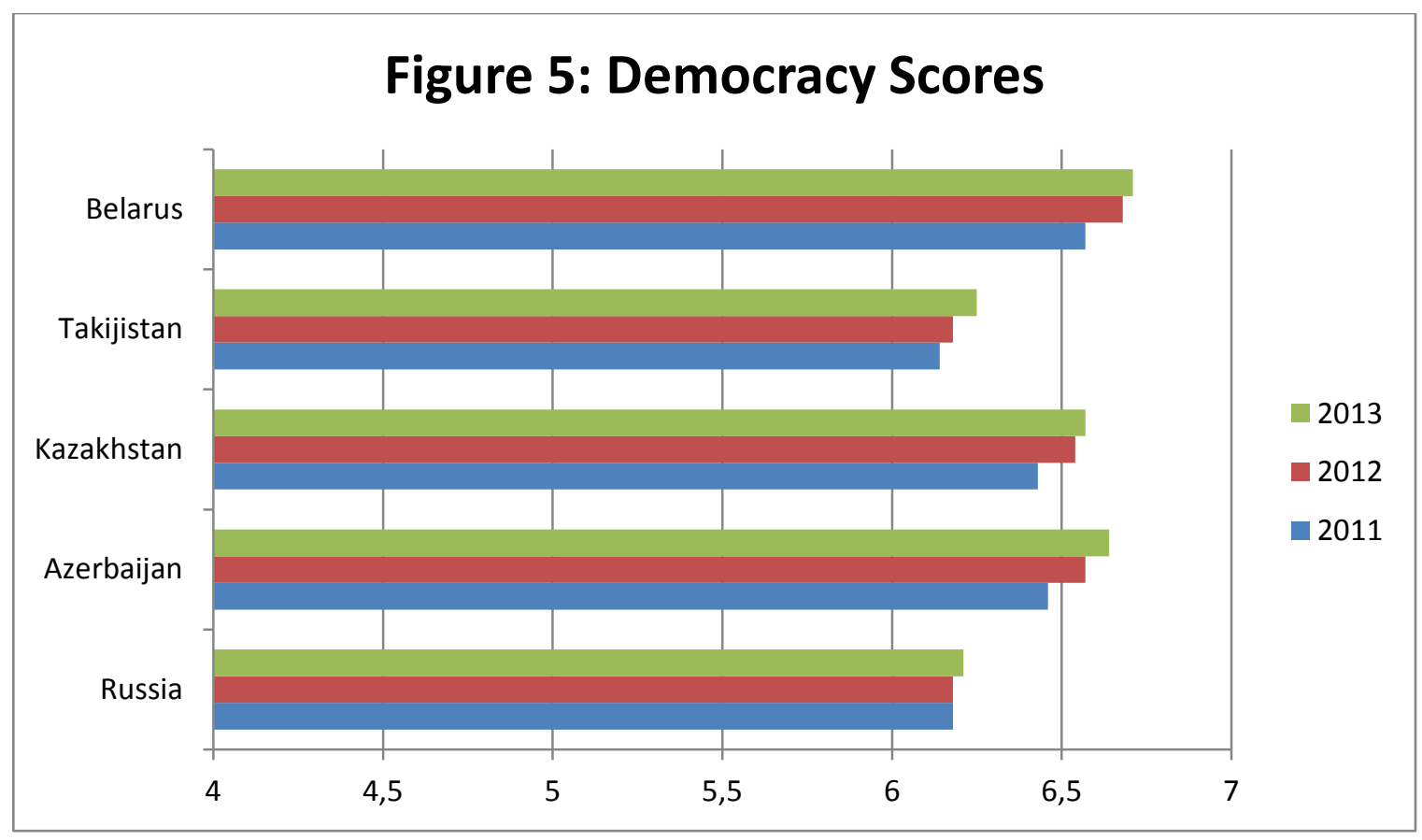

Source: Calculated from Nations in Transit data, Freedom House (2013) 


\section{Figure 6: Civil Society in Kazakhstan}

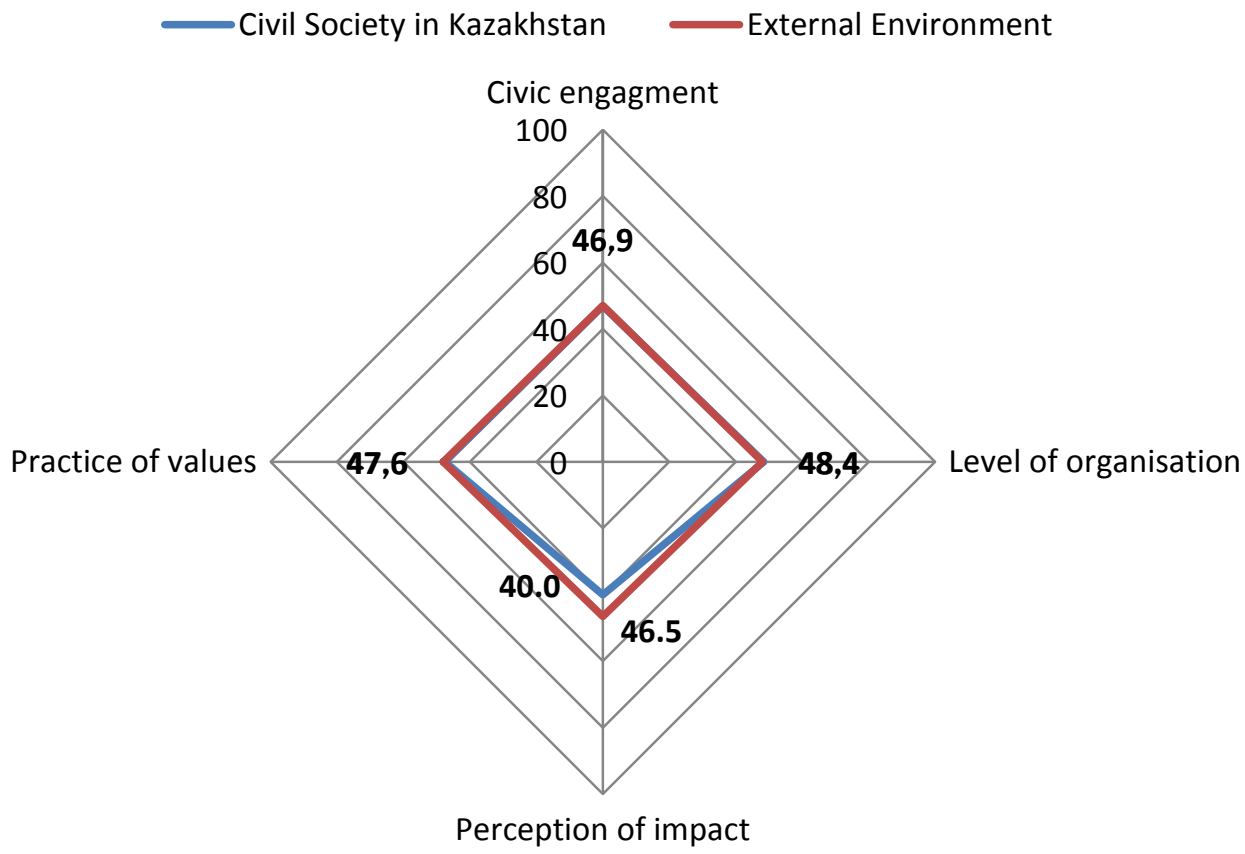

Source: redrawn from Civil Society Index Civicus (2011) 


\begin{tabular}{|l|l|r|r|}
\hline \multicolumn{3}{|c|}{ Table 1: Civil Society and Democracy in Kazakhstan and neighbouring CIS countries } \\
\hline & & Democracy score & Civil society score \\
\hline Democracy score & Pearson Correlation & 1 & $.943^{* *}$ \\
& Sig. (2-tailed) & 70 & .000 \\
& $\mathrm{~N}$ & $.943^{* *}$ & 70 \\
\hline Civil society & Pearson Correlation & .000 & 1 \\
& Sig. (2-tailed) & 70 & 70 \\
\hline
\end{tabular}

** Correlation is significant at the 0.01 level (2-tailed)

Source: Correlation analysis conducted using Freedom House data (2004-2013)

Table 2: BTI Index - Kazakhstan Civil Society data

\begin{tabular}{|l|l|l|l|l|}
\hline & 2006 & 2008 & 2010 & 2012 \\
\hline Extent of civil society traditions & 9 & 7 & 7 & 7 \\
\hline Extent of civil society participation in political process & 4 & 3 & 3 & 3 \\
\hline
\end{tabular}

Source: Bertelsmann Stiftung's Transformation Index (2012) 